\title{
KINERJA KEPALA SMP NEGERI 14 BALIKPAPAN DITINJAU DARI STANDAR PENGELOLAAN TAHUN AJARAN 2019/2020
}

\author{
Ferdinandus Jerana ${ }^{1}$, Moch. Alipatan ${ }^{2}$, Rahayu Sri Waskitoningtyas ${ }^{3}$ \\ Universitas Balikpapan ${ }^{1}$, Universitas Balikpapan ${ }^{2}$, Universitas Balikpapan ${ }^{2}$ \\ pos-el: ferdyjerana93@gmail.com ${ }^{1}$, alipatan@gmail.com².rahayu.sri@uniba-bpn.ac.id ${ }^{3}$
}

\begin{abstract}
ABSTRAK
Penelitian ini bertujuan untuk mendeskripsikan pelaksanaan standar pengelolaan pendidikan yang terdiri dari:(1) Kinerja kepala sekolah menetapkan visi, misi dan tujuan dan mengembangkan serta merumuskan kelembagaan (2) Kinerja kepala sekolah dalam menetapkan struktur organisasi sekolah dan rincian tugastugas setiap personil dalam struktur organisasi (3) Kinerja kepala sekolah tersusunnya dalam pelaksanaannya dibidang kurikulum (4) Kinerja kepala sekolah sebagai pemimpin pembelajaran dalam pengelolaan sekolah. Penelitian ini menggunakan pendekatan kualitatif deskriptif. Teknik pengumpulan data menggunakan wawancara, observasi dan dokumen. Sumber informasi dalam penelitian ini adalah Kepala Sekolah dan 3 Guru matematika. Hasil penelitian menunjukkan sebagai berikut : (1) Kinerja kepala sekolah terkait visi, misi dan tujuan telah ditetapkan oleh kepala sekolah selanjutnya dirumuskan berdasarkan masukan dari warga sekolah, komite sekolah dan diputuskan dalam rapat. (2) Kinerja kepala sekolah terkait dengan struktur organisasi sekolah diputuskan dengan dewan pendidikan yang dipimpin oleh kepala sekolah, ditetapkan dan disosialisasikan oleh kepala sekolah. (3) Kinerja kepala sekolah dibidang kurikulum dengan menyusun kurikulum tingkat satuan pendidikan yang berpedoman kurikulum 2013 dengan memperhatikan standar kompetensi lulusan, isi, proses, dan penilaian serta peraturan pelaksanaan lainnya. (4) Kinerja kepala sekolah dalam kaitannya sebagai pemimpin pembelajaran yaitu dengan mengembangkan motivasi pendidikan, menjamin mutu proses pembelajaran, dan mengembangkan sistem penilaian.
\end{abstract}

\section{Kata kunci : Kinerja Kepala Sekolah, Standar Pengelolaan.}

\section{ABSTRACT}

This study aims to describe the implementation of standards education management which consists of: (1) the performance of the principal in determining the vision, mission and goals and developing and formulating institutions (2) the performance of the principal in determining the school organizational structure and the details of the duties of each personnel in the organizational structure (3) the performance of the principal compilation in its implementation in the field of curriculum (4) The performance of the principal as a learning leader in school management. This research uses a descriptive qualitative approach. Data collection techniques using interviews, observation and documents. Sources of information in this study were the principal and 3 mathematics teachers. The data analysis technique used was data reduction, data presentation, and conclusion drawing. The results showed the following: (1) The principal's performance related to the vision, mission and goals set by the principal was then formulated based on input from the school community, school committee and decided in a meeting. (2) The performance of the principal in relation to the school organizational structure is decided by an education board led by the principal, stipulated and socialized by the principal. (3) The performance of the principal in the curriculum sector by compiling a curriculum at the level of an educational unit based on the 2013 curriculum by taking into account the standard of graduate composition, content, process, and assessment as well as other implementing regulations. (4) The principal's performance in relation to learning leaders was shown by develops educational motivation, guarantees the quality of the learning process, develops an assessment system.

Keywords: Principal Performance, Management Standards 


\section{PENDAHULUAN}

Prestasi sekolah yang baik diperlukan pengelolaan sekolah yang baik. Pengelolaan sekolah yang baik dibutuhkan suatu standar khusus agar terjadi pemerataan di tiap sekolah. Standar pengelolaan pendidikan diatur dalam peraturan Menteri Pendidikan Nasional nomor 19 tahun 2007. Peraturan menteri pendidikan nasional terdapat hal-hal yang harus diperhatikan dalam pengelolaan pendidikan di antaranya perencanaan program, pelaksanaan rencana kerja, pengawasan, dan evaluasi. Kepemimpinan sekolah sistem informasi manajemen dan penilaian khusus.

Melihat realita dan fakta tersebut maka perlu motivasi kuat bagi pengelola, pendidik dan tenaga kependidikan sekolah untuk mengelola sekolah menjadi efektif untuk menjadikannya sebuah lembaga yang potensial. Kuncinya tentu saja pengelolaan sekolah yang efektif yang menjunjung pengabdian serta mengarah profesionalisme baik dalam pengadaan sarana, penerapan metode pembelajaran dan kurikulum serta rekrutmen tenaga pendidik dan kependidikan.

Sebagai penanggung jawab pendidik dan pembelajaran disekolah kepala sekolah hendak dapat meyakinkan kepada masyarakat bahwa segala sesuatunya telah berjalan dengan baik termasuk perencanaan pelaksanaan, evaluasi, dan penyediaan serta pemanfaatan sumber daya guru, sumber daya manusia, kerja sama sekolah dan orang tua Pada tingkat operasional

Kepala sekolah adalah orang yang berada di garis terdepan yang mengkoordinasikan upaya meningkatkan pembelajaran yang bermutu. Kepala sekolah diangkat untuk menduduki jabatan bertanggung jawab mengkoordinasikan upaya bersama mencapai tujuan pendidikan pada level sekolah yang dipimpin.

Kepemimpinan adalah proses mempengaruhi, mendorong, dan menggerakkan orang lain agar berpikir, bertindak, dan bekerja sesuai dengan aturan yang berlaku untuk mencapai tujuan yang telah ditetapkan. Purwanto (2002) menjelaskan kepemimpinan adalah kemampuan untuk mempengaruhi sebuah kelompok untuk mencapai suatu visi atau tujuan tertentu. Sofan (2013) memaparkan kepemimpinan adalah kemampuan untuk menggerakkan pelaksanaan pendidikan, sehingga tujuan pendidikan yang telah ditetapkan dapat tercapai secara efektif dan efisien. Wahjosumidjo (2011) berpendapat bahwa kepala sekolah harus memahami tugas dan fungsinya demi keberhasilan sekolah serta memiliki kepedulian kepala staf dan siswa.

Hal tersebut di atas diperkuat oleh penelitian yang dilakukan oleh (Salim, 2017) menyatakan bahwa peningkatan efektivitas pengelolaan dapat dilakukan dengan penguatan kemampuan manajemen kepala sekolah. Selain itu penelitian yang dilakukan oleh (Marsiana Lina, 2017) dengan menyatakan bahwa perencanaan dan pelaksanaan pengelolaan sekolah dilaksanakan dengan baik serta faktor pendukung program sekolah terdapat dukungan dari warga sekolah.

Berdasarkan uraian latar belakang di atas peneliti tertarik untuk meneliti tentang Kinerja Kepala SMP Negeri 14 di Tinjau dari Standar Pengelolaan.

\section{METODE PENELITIAN}

Penelitian ini adalah penelitian kualitatif yang bersifat deskriptif yaitu jenis penelitian yang menggambarkan tentang suatu gejala, kondisi, dan situasi yang ada. Menurut Purwanto (2012) penelitian deskriptif adalah penelitian yang hanya melibatkan satu variabel pada satu kelompok, tanpa menghubungkan dari variabel lain atau membandingkan dengan kelompok lain. Tujuan dari penelitian deskriptif ini adalah untuk membuat deskripsi atau gambaran langsung kinerja kepala sekolah ditinjau dari standar pengelolaan 
Lokasi penelitian ini dilaksanakan di SMP Neger 14 Balikpapan. Dalam penelitian ini informan yaitu kepala SMP Negeri 14 Balikpapan serta 3 guru matematika yang diambil secara purposive sampling.

Teknik pengumpulan data yang dilakukan adalah metode observasi, wawancara, dan dokumentasi. Teknik analisis data yang digunakan adalah reduksi data, penyajian data, dan kesimpulan/verifikasi data.

\section{HASIL DAN PEMBAHASAN}

Berdasarkan hasil penelitian maka akan dijelaskan secara berurutan mengenai:

\section{a. Kinerja Kepala Sekolah Terkait Visi,} Misi dan Tujuan

Visi adalah tujuan yang akan dicapai oleh sekolah selama paling tidak lima tahunan yang menyangkut mutu akademik, pemenuhan sarana dan prasarana, dan manajemen sekolah. Visi disusun berdasarkan pada analisis SWOT pada kondisi yang ada di sekolah. Melibatkan seluruh stakeholders sekolah pada proses penyusunan dan sosialisasi. visi SMP Negeri 14 Balikpapan sudah cukup baik karena telah memenuhi unsur terbentuknya visi sekolah tersebut. Aspek penegasan tersebut meliputi visi SMP Negeri 14 Balikpapan berorientasi pada masa depan yaitu apa yang akan dicapai oleh sekolah selama lima tahun mendatang, gambaran visi yang bersifat umum memberikan penjelasan bahwa tidak disusun menggunakan dasar kondisi saat ini, selain itu visi sekolah berusaha memadukan tiga unsur utama berupa prestasi, kehidupan keagamaan, serta pembinaan karakter yang hendak dicapai sekolah. Visi sekolah ditambahkan dengan indikator yang memberikan penegasan dan arahan bagi sekolah, sehingga dapat memacu setiap anggota organisasi untuk turut serta meningkatkan pencapaian visi sekolah.

Rumusan misi sebagai salah satu bentuk kiat atau cara untuk mencapai visi sekolah, penyusunan misi dengan melibatkan seluruh warga sekolah dan berbagai pihak yang berkepentingan. Setelah misi sekolah disusun, maka proses sosialisasi dilakukan melalui berbagai forum pertemuan, diskusi dan pembinaan, serta didukung dengan adanya dokumen atau petunjuk kerja tentang misi sekolah. maka misi yang disusun SMP Negeri 14 Balikpapan sudah cukup baik karena memenuhi ciri-ciri misi yang baik tersebut.

Selanjutnya tujuan pendidikan yaitu agar peserta didik memiliki kekuatan spiritual keagamaan, pengendalian diri, kepribadian, kecerdasan, akhlak mulia, serta keterampilan yang diperlukan dirinya, masyarakat, bangsa dan negara. Hal ini berarti proses pembelajaran diarahkan untuk pembentukan sikap dan kepribadian, pengembangan kecerdasan intelektual, serta mengembangkan keterampilan peserta didik sesuai dengan kebutuhannya. Dalam upaya mencapai tujuan pembelajaran, terdapat beberapa komponen yang perlu diperhatikan. Komponen tersebut antara lain tujuan pembelajaran, materi atau bahan ajar, strategi belajar mengajar, dan evaluasi atau penilaian Rusman (2011). Komponen tujuan pembelajaran menggambarkan proses dan hasil belajar yang diharapkan dicapai oleh peserta didik sesuai dengan kompetensi dasar yang ditetapkan. Komponen 3 materi atau bahan ajar memuat fakta, konsep, prinsip, dan prosedur yang relevan sesuai dengan indikator tujuan pembelajaran.

Berdasarkan keseluruhan data yang sudah diuraikan bahwa tujuan SMP Negeri 14 Balikpapan mengenai standar pengelolaan sekolah sudah sangat baik karena telah memenuhi unsur standar pengelolaan sekolah dan dirumuskan berdasarkan masukan warga sekolah untuk mencapai tujuan pembelajaran yang diharapkan oleh peserta didik.

Dengan demikian dari hasil temuan peneliti kemudian didukung oleh beberapa teori dapat disimpulkan kinerja kepala sekolah terkait visi, misi dan tujuan telah 
dirumuskan oleh kepala sekolah selanjutnya ditetapkan berdasarkan masukan dari warga sekolah, komite sekolah dan diputuskan dalam rapat dengan dibuktikan adanya berita acara dan daftar hadir kegiatan perumusan, penetapan, dan sosialisasi visi, misi dan tujuan.

\section{b. Kinerja Kepala Sekolah Terkait Struktur Organisasi}

Struktur organisasi merupakan suatu susunan atau penempatan orang-orang dalam satu kelompok sehingga dapat tersusun pola kegiatan yang tertuju pada tercapainya tujuan bersama dalam kelompok tersebut. Sekolah sebagai suatu lembaga pendidikan yang di dalamnya terdapat berbagai unsur memerlukan tatanan kerja sama yang baik maupun ketentuan tugas yang menyangkut hak, kewajiban dan tanggung jawab pribadi maupun kelompok demi kelancaran penyelenggaraan program-program kegiatan sekolah. Untuk mencapai maksud tersebut diperlukan struktur organisasi yang baik dan sistematis.

Menurut Handoko (2013), struktur organisasi disusun adalah untuk membantu pencapaian tujuan organisasi dengan lebih efektif. Tujuan yang akan menentukan seluruh tugas pekerjaan, hubungan antar tugas, batas wewenang dan tanggung jawab untuk melaksanakan masing-masing tugas tersebut. Atas dasar kegiatan-kegiatan itu selanjutnya disusun pola tetap hubungan-hubungan di antara bidang-bidang keputusan, maupun pelaksana yang mempunyai kedudukan, wewenang, dan tanggung jawab tertentu dan semua itu akan menghasilkan kerangka struktur organisasi.

Berdasarkan pembahasan di atas struktur organisasi SMP Negeri 14 Balikpapan sudah sesuai dengan standar pendidikan di mana terdapat kepala sekolah sebagai komando dalam pengelolaan sekolah staf tenaga kependidikan dengan staf lainnya bersifat koordinasi yang telah ditetapkan melalui langkah-langkah diputuskan melalui rapat kemudian disahkan. Bentuk susunan struktur organisasi SMP Negeri 14 kepala sekolah memiliki wakil kepala sekolah terdapat pembagian urusan, yang meliputi urusan kurikulum, sarana dan prasarana, kesiswaan dan humas

Dengan demikian dapat dinyatakan terkait dengan struktur organisasi dalam temuan peneliti dan dukungan teori dapat disimpulkan kinerja kepala sekolah terkait dengan struktur organisasi sekolah diputuskan dengan dewan pendidikan yang dipimpin oleh kepala sekolah, ditetapkan dan disosialisasikan oleh kepala sekolah selanjutnya dibuktikan pengesahan oleh dinas pendidikan.

\section{c. Kinerja Kepala Sekolah Terkait Kurikulum}

Kurikulum merupakan nilai-nilai keadilan dalam inti pendidikan. Istilah tersebut mempengaruhi terhadap kurikulum yang akan direncanakan dan dimanfaatkan. Secara terminologi, kurikulum berarti suatu program pendidikan yang berisikan berbagai bahan ajar dan pengalaman belajar yang diprogramkan, direncanakan dan dirancangkan secara sistematika atas dasar norma-norma yang berlaku dan dijadikan pedoman dalam proses pembelajaran bagi pendidik untuk mencapai tujuan pendidikan.

Kurikulum itu memuat semua program yang dijalankan untuk menunjang proses pembelajaran. Program yang dituangkan tidak terpancang dari segi administrasi saja tetapi menyangkut keseluruhan yang digunakan untuk proses pembelajaran Dakir (2010).

Berdasarkan hasil pencermatan dokumen, observasi dan wawancara peneliti di SMP Negeri 14 Balikpapan pengelolaan kurikulum sudah sesuai dengan standar pendidikan dikarenakan tim pengembang sekolah ikut serta dalam proses penyusun kurikulum yang ditetapkan dengan hasil rapat dan dipimpin oleh kepala sekolah. 
Terkait hal tersebut hasil temuan peneliti dan dukungan teori dapat disimpulkan kinerja kepala sekolah dibidang kurikulum dengan menyusun kurikulum tingkat satuan pendidikan yang berpedoman kurikulum 2013 dengan memperhatikan standar kompetensi lulusan, isi, proses, dan penilaian serta peraturan pelaksanaan lainnya dibuktikan dengan adanya kalender pendidikan meliputi jadwal pembelajaran semester ganjil dan genap, penilaian tengah semester, penilaian akhir semester, kegiatan ekstrakurikuler dan hari libur.

\section{d. Kinerja Kepala Sekolah Terkait Kepimpinan Pembelajaran}

Pengelolaan sekolah yang akuntabel, diperlukan pola kepemimpinan yang mendukungnya. Penanggung jawab kepemimpinan sekolah adalah kepala sekolah, dengan dibantu oleh wakil kepala sekolah. Pada pelaksanaan tugas, kepala sekolah dapat mendelegasikan kewenangan yang menjadi tanggung jawabnya kepada wakil kepala sekolah maupun pendidik dan tenaga kependidikan yang dipandang mampu untuk melaksanakan tugas kepala sekolah.

Kepemimpinan sekolah pada hakikatnya melaksanakan pengelolaan secara akuntabel dan transparan, sehingga mendukung pencapaian mutu sekolah secara optimal. Tanggung jawab utama merupakan kewenangan dari kepala sekolah, akan tetapi pelaksanaan kepemimpinan dibantu oleh wakil kepala sekolah. Berdasarkan hasil penelitian tersebut, maka aspek pengelolaan kepemimpinan sekolah sudah sesuai dengan indikator yang ditetapkan.

Kemampuan dan pelaksanaan kepala sekolah sebagai penanggung jawab pengelolaan sekolah mampu memberikan pandangan jauh ke depan (visioner) dan menjadi teladan yang baik bagi semua warga sekolah. Pelaksanaan tugas kepala sekolah sesuai dengan deskripsi tugas yang dituangkan pada job description di ruang kepala sekolah. Berdasarkan hasil penelitian tersebut, maka aspek kemampuan dan pelaksanaan tugas kepala sekolah sesuai dengan indikator yang ditetapkan.

Dengan demikian dari berbagai hasil temuan selanjutnya didukung beberapa teori maka dapat disimpulkan kinerja kepala sekolah dalam kaitannya sebagai pemimpin pembelajaran mengembangkan motivasi pendidikan, menjamin mutu proses pembelajaran, mengembangkan sistem penilaian dan dibuktikan laporan supervisi proses pembelajaran secara teratur tiap semester.

\section{KESIMPULAN}

Kinerja kepala sekolah terkait visi, misi dan tujuan telah ditetapkan oleh kepala sekolah selanjutnya dirumuskan berdasarkan masukan dari warga sekolah, komite sekolah dan diputuskan dalam rapat dengan dibuktikan adanya berita acara dan daftar hadir kegiatan perumusan, penetapan, dan sosialisasi visi, misi dan tujuan.

Kinerja kepala sekolah terkait dengan struktur organisasi sekolah diputuskan dengan dewan pendidikan yang dipimpin oleh kepala sekolah, ditetapkan dan disosialisasikan oleh kepala sekolah selanjutnya dibuktikan pengesahan oleh dinas pendidikan.

Kinerja kepala sekolah dibidang kurikulum dengan menyusun kurikulum tingkat satuan pendidikan yang berpedoman kurikulum 2013 dengan memperhatikan standar kompetensi lulusan, isi, proses, dan penilaian serta peraturan pelaksanaan lainnya dibuktikan dengan adanya kalender Pendidikan meliputi jadwal pembelajaran semester ganjil dan genap, penilaian tengah semester, penilaian akhir semester, kegiatan ekstrakurikuler dan hari libur.

Kinerja kepala sekolah dalam kaitannya sebagai pemimpin pembelajaran mengembangkan motivasi pendidikan, menjamin mutu proses pembelajaran, mengembangkan sistem penilaian dan 
dibuktikan laporan supervisi proses pembelajaran secara teratur tiap semester.

\section{DAFTAR PUSTAKA}

Dakir, H. (2010). Perencanaan dan Pengembangan Kurikulum. Jakarta: Rineka Cipta.

Handoko, H. (2013). Organisasi Perusahaan: Teori, Struktur dan Perilaku. Yogyakarta: BPFE.

Marsiana Lina, H. M. (2017). Pengelolaan Sekolah Adiwiyata Oleh Kepala Sekolah.

purwanto. (2002). hubungan Gaya kepemimpinan deangan komitmen terhadap organisasi.

Purwanto. (2012). Metodologi Penelitian Kuantitatif. Yogyakarta: Pustaka Pelajar.

Rusman. (2011). Model-model Pembelajaran Mengembangkan Profesionalisme Guru. Jakarta: PT Raja Grafindo.

Salim, N. A. (2017). Peningkatan Efektivitas Pengelolaan Sekolah Melalui Penguatan Kemampuan Manajerial Kepala Sekolah.

sofan, a. (2013). Pengembangan dan Model Pembelajaran dalam Kurikulum. jakarta: prestasi pustakaraya.

Wahjosumidjo. (2010). Kepemimpinan Kepala Sekolah, Tinjauan Teoritik dan Permsasalahannya. jakarta: PT. Raja Grafindo Persada.

Wahjosumidjo. (2011). Kepemimpinan Kepala Sekolah. jakarta: PT. RajaGrafindo Persada. 